\title{
Solar Based Automatic Braking System
}

\author{
Muhammad Meidi \\ Jurusan Teknik Elektro, Fakultas Teknik, Universitas Negeri Semarang \\ muhammadmeidi14@students.unnes.ac.id \\ Esa Apriaskar \\ Jurusan Teknik Elektro, Fakultas Teknik, Universitas Negeri Semarang \\ esa.apariaskar@mail.unnes.ac.id \\ Djuniadi \\ Jurusan Teknik Elektro, Fakultas Teknik, Universitas Negeri Semarang \\ djuniadi@mail.unnes.ac.id
}

\begin{abstract}
Solar based automatic braking system. This tool is used as an automatic braking system when a vehicle sees an object in front of it. The HC-SR04 ultrasonic sensor is mounted on a system that is used as an object signal receiver, with Arduino as a control to control motor speed and brakes automatically when seeing an object right in front of the vehicle with a certain distance. The braking is carried out using a PWM speed control system, while the driver used for the motorbike is L298N. as clean energy and reduce waste of costs in the use of electricity, this tool uses solar cells as a power source or as a battery charger.
\end{abstract}

Keywords - Automatic braking, HC-SR04 Ultrasonic Sensor, Micro Controler (Arduino Uno), PWM, L298N Motor Driver.

\begin{abstract}
Abstrak
Solar based automatic braking system. Alat ini digunakan sebagai sistem pengereman otomatis ketika suatu kendaraan melihat ada objek didepan-nya. Sensor ultrasonic HC-SR04 yang dipasang pada sebuah sistem yang digunakan sebagai penerima sinyal objek, dengan arduino sebagai kontrol untuk mengendalikan kecepatan motor serta mengerem secara otomatis ketika melihat objek berada tepat didepan kendaraan dengan jarak tertentu. Pengereman yang dilakukan alat ini menggunakan sistem pengendali kecepatan PWM, sedangkan driver yang digunakan untuk motornya yaitu L298N. sebagai energy bersih dan mengurangi pemborosan biaya dalam penggunaan listrik alat ini menggunakan solar cell sebagai sumber dayanya atau sebagai charger batrenya.
\end{abstract}

Kata kunci: Pengereman otomatis, Sensor Ultrasonik HC-SR04, Micro Controler(Arduino Uno), PWM, Driver Motor L298N.

\section{PENDAHULUAN}

Maraknya terjadi kecelakan akibat kelalaian pengemudi sering terjadi disekitar kita. Data yang didapat dari Kompas.com Pada tahun 2018 lalu, angkanya mencapai 36.481 kejadian. Sedangkan pada periode yang berjalan tahun 2019 ini, mencatat 5.277 kecelakaan.

Untuk itu perlu adanya cara atau solusi untuk menyelesaikan masalah tersebut, yaitu dengan menambahkan sistem pada sebuah kendaraan tersebut berupa 
pengereman secara otomatis, dengan sistem tersebut diharapkan angka kecelakaan dapat berkurang atau bahkan tidak ada lagi kecelakaan kendaraan akibat kelalain pengemudi dalam mengendarai kendaraan. Sistem ini dapat juga mendukung dikembangkannya teknologi baru pada kendaraan tanpa pengemudi atau pengemudi otomatis(auto drive).

Sistem ini dapat diterapkan semua jenis kendaraan terutama kendaraan yang berbahan bakar listrik. Karena akan lebih efektif dan efesien dalam pengemudi menerapkan sistem tersebut, untuk mengurangi pemborosan biaya dalam penggunaan listrik, sistem ini menggunakan panel surya sebagai pembantu dalam pengecasan batre atau aki pada mobil listrik

\section{DESAIN SISTEM}

Perancangan automatic braking sistem ini terinspirasi karena keprihatinan terhadap angka kecelakan yang terjadi, dengan adanya alat ini sebagai miniature atau sebagai percobaan yang mungkin akan diaplikasi pada semua kendaraan maka akan mengurangi angka kecelakaan tersebut. Sistem ini dirancang meliputi sensor ultrasonic HC-SR04, Arduino nano, diver L298N, Dc motor

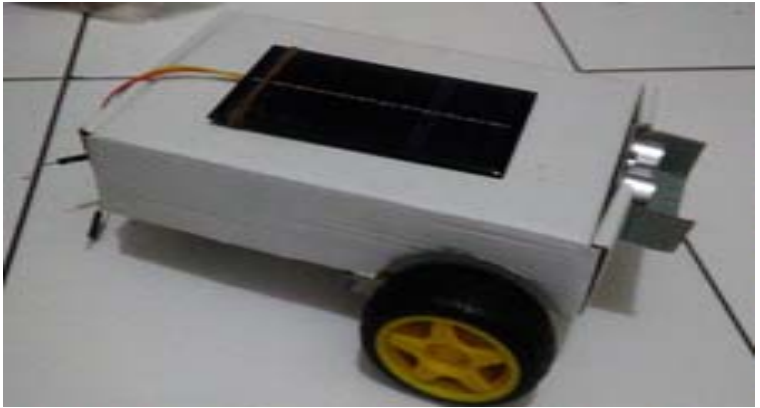

Gambar 1. Desain alat

Sistem ini bekerja saat sensor ultrasonic memancarkan gelombang suara dan menerima pantulan dari gelombang suara tersebut dan diubah menjadi besaran listrik kemudian besaran listrik tersebut yang besarnya tergantung jarak objek pemantulan dikirimkan kearduino sebagai mikro kontroler yang akan mengatur besaran listrik tersebut, kemudian arduino akan memberikan sinyal hasil olahan besaran listrik dari sensor ultrasonic dengan metode PWM ke driver motor DC L298N sebagai pengatur kecepatan motor DC tersebut, maka kecepatan motor akan berubah sesuai jarak yang telah diatur dan akan berhenti pada jarak yang juga telah diatur melalui program mikrokontroler arduino uno.

\section{SENSOR ULTRASONIK HC-SR04}

Sensor ultrasonik adalah sebuah sensor yang berfungsi untuk mengubah besaran fisis (bunyi) menjadi besaran listrik dan sebaliknya. 


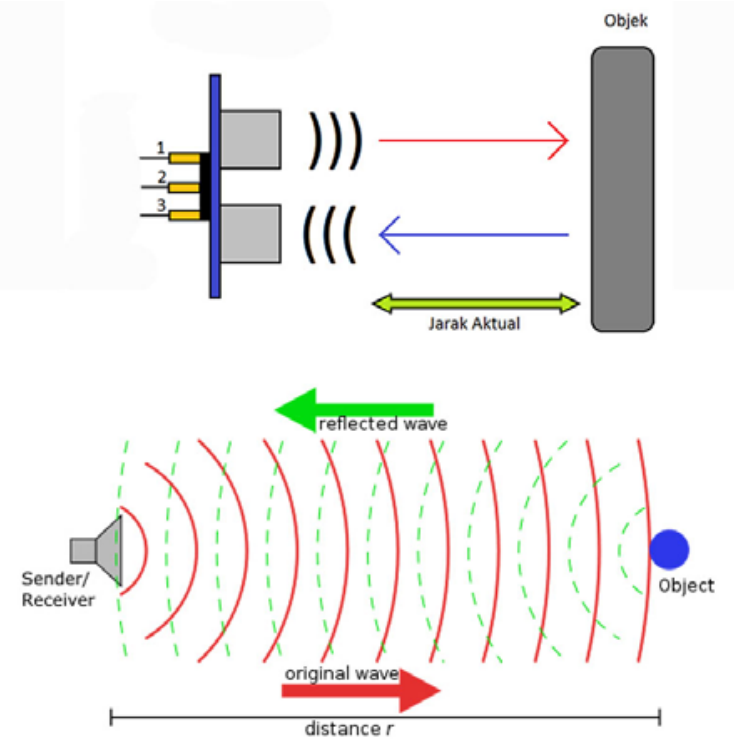

Gambar 2. cara kerja sensor ultrasonik dengan transmitter dan receiver

Rangkaian sensor ultrasonic terdiri dari 3, yaitu

\section{Piezoelektrik}

Piezoelektrik berfungsi untuk mengubah energi listrik menjadi energi mekanik.

\section{Transmitter}

Transmitter adalah sebuah alat yang berfungsi sebagai pemancar gelombang ultrasonik dengan frekuensi tertentu (misal, sebesar $40 \mathrm{kHz}$ ) yang dibangkitkan dari sebuah osilator.

\section{Receiver}

Receiver terdiri dari transduser ultrasonik menggunakan bahan piezoelektrik, yang berfungsi sebagai penerima gelombang pantulan yang berasal dari transmitter yang dikenakan pada permukaan suatu benda atau gelombang langsung LOS (Line of Sight) dari transmitter.

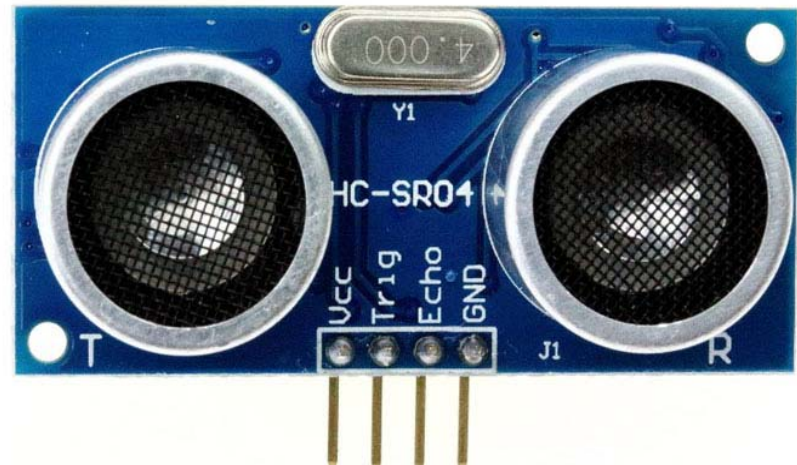

Gambar 3. Sensor Ultrasonik HC-SR04

Sensor ultrasonic HC-SR04 merupakan sensor ultrasonik siap pakai, satu alat yang berfungsi sebagai pengirim, penerima, dan pengontrol gelombang ultrasonik. Alat ini bisa digunakan untuk mengukur jarak benda dari 2cm - 4m dengan akurasi 3mm. Alat ini memiliki 4 pin, pin Vcc, Gnd, Trigger, dan Echo. Pin Vcc untuk listrik positif dan Gnd untuk ground-nya. Pin Trigger untuk trigger keluarnya sinyal dari sensor dan pin Echo untuk menangkap sinyal pantul dari benda.

\section{MICROKONTROLLER (ARDUINO UNO)}

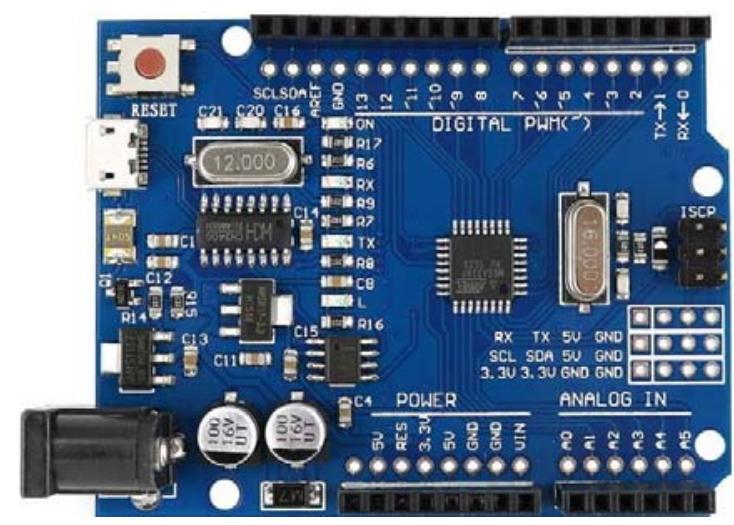

Gambar 4. Arduino Mega 
Arduino adalah jenis software Manfaat penggunaan arduino yaitu: pengendali mikro berupa single board dengan

1. Murah,

lisensi open source yang merupakan turunan

2. Operating sistem fleksibel, dari Wiring platform. Memiliki 14 pin input

3. Bahasa program sederhana, dari output digital dimana 6 pin input

4. Open source.

tersebut dapat digunakan sebagai output PWM dan 6 pin input analog, $16 \mathrm{MHz}$ osilator kristal, koneksi USB, jack power, ICSP header, dan tombol reset. Untuk mendukung mikrokontroler agar dapat digunakan, cukup hanya menghubungkan Board Arduino Uno ke komputer dengan menggunakan kabel USB atau listrik dengan AC yang-ke adaptor-DC atau baterai untuk menjalankannya. Kegunaan arduino ialah untuk memudahkan penggunaan rekayasa elektronik untuk diaplikasikan pada berbagai bidang, salah satunya yaitu project ini.

Daya

Kisaran kebutuhan daya yang disarankan untuk board Uno adalah 7 sampai dengan 12 volt, jika diberi daya kurang dari 7 volt kemungkinan pin $5 \mathrm{v}$ Uno dapat beroperasi tetapi tidak stabil kemudian jika diberi daya lebih dari $12 \mathrm{~V}$, regulator tegangan bisa panas dan dapat merusak board Uno.

\section{Input dan Output}

Masing-masing dari 14 pin digital di Uno dapat digunakan sebagai input atau output, dengan menggunakan fungsi pinMode (), digitalWrite (), dan digitalRead (), beroperasi dengan daya 5 volt. Setiap pin dapat memberikan atau menerima maksimum $40 \mathrm{~mA}$ dan memiliki internal pull-up resistor (secara default terputus) dari 20-50 kOhms. Selain itu, beberapa pin memiliki fungsi khusus:

Serial: 0 (RX) dan 1 (TX). Digunakan untuk menerima (RX) dan mengirimkan (TX) TTL data serial.

PWM: 3, 5, 6, 9, 10, dan 11. Menyediakan output PWM 8-bit dengan fungsi analogWrite ().

SPI: 10 (SS), 11 (Mosi), 12 (MISO), 13 (SCK). Pin ini mendukung komunikasi SPI menggunakan SPI library.

LED: 13. Ada built-in LED terhubung ke pin digital 13. Ketika pin bernilai nilai HIGH, LED on, ketika pin bernilai LOW, LED off. Uno memiliki 6 masukan analog, berlabel A0 sampai dengan A5, yang masing-masing menyediakan 10 bit dengan resolusi (yaitu 
1024 nilai yang berbeda). Selain itu, beberapa pin memiliki fungsi khusus:

I2C: A4 (SDA) dan A5 (SCL). Dukungan I2C (TWI) komunikasi menggunakan perpustakaan Wire.

Aref. Tegangan referensi (0 sampai 5V saja) untuk input analog. Digunakan dengan fungsi analogReference ().

Reset. Tombol merah untuk me-reset mikrokontroler.

\section{PWM (Pulse Width Modulation)}

Suatu teknik modulasi yang mengubah lebar pulsa (pulse width) dengan nilai frekuensi dan amplitudo yang tetap. PWM atau Pulse Width Modulation ini digunakan menghasilkan sinyal analog dari perangkat Digital (contohnya dari Mikrokontroller). sinyal PWM dengan siklus kerja 60\% , sinyal PWM hanya ON untuk 60\% dari suatu periode waktu.

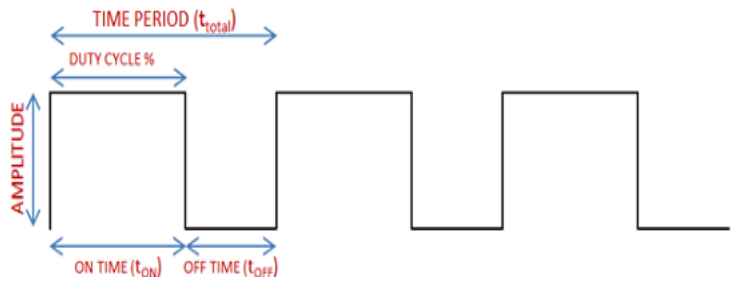

Gambar 5. Sinyal PWM

Untuk menghitung tegangan output sinyal PWM yaitu jika Tegangan output sinyal PWM yang telah diubah menjadi analog akan menjadi persentase dari siklus kerja (Duty Cycle). Misalnya jika tegangan operasi 5V maka sinyal PWM juga akan

memiliki 5V ketika tinggi. Apabila Duty Cycle atau siklus kerja adalah 100\%, maka tegangan output akan menjadi 5V. Sedangkan untuk siklus kerja 50\% akan menjadi 2.5V. Demikian juga apabila siklus kerja 60\% maka Tegangan Output analognya akan menjadi 3V.

Rumus perhitungan tegangan output sinyal PWM ini dapat dilihat seperti persamaan dibawah ini :

$\mathrm{V}_{\text {out }}=$ Duty Cycle $\mathrm{x} \mathrm{V}_{\text {in }}$

\section{DRIVER MOTOR L298N}

Driver motor L298N merupakan module driver motor DC yang paling banyak digunakan atau dipakai di dunia elektronika yang difungsikan untuk mengontrol kecepatan serta arah perputaran motor DC.

IC L298 merupakan sebuah IC tipe Hbridge yang mampu mengendalikan bebanbeban induktif seperti relay, solenoid, motor DC dan motor stepper. Pada IC L298 terdiri dari transistor-transistor logik (TTL) dengan gerbang nand yang berfungsi untuk memudahkan dalam menentukan arah putaran suatu motor dc maupun motor stepper. 


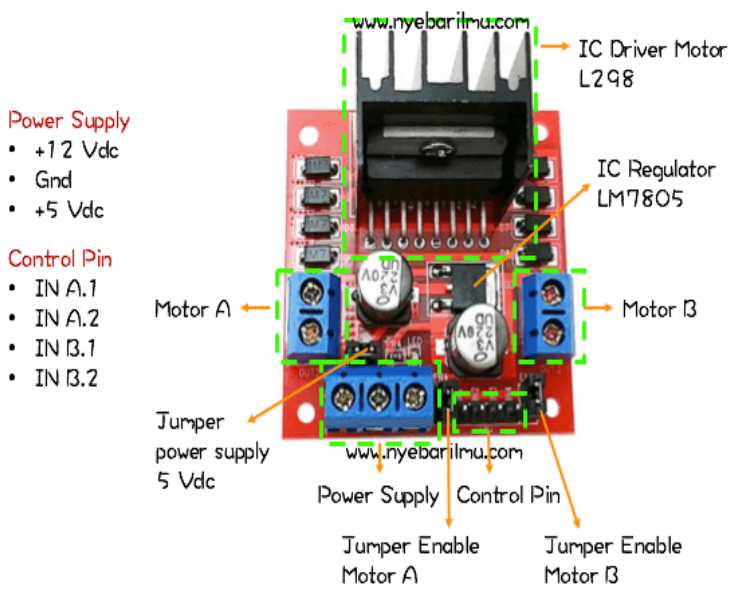

Gambar 6. Pin pin driver motor L298N

Keterangan :

- Enable A : berfungsi untuk mengaktifkan bagian output motor A

- Enable B : berfungsi untuk mengaktifkan bagian output motor B

- Jumper 5vdc : sebagai mode pemilihan sumber tegangan 5Vdc, jika tidak dijumper maka akan ke mode sumber tegangan $12 \mathrm{Vdc}$

- Control Pin : Sebagai kendali perputaran dan kecepatan motor yang dihubungkan ke Mikrokontroler

\section{PRINSIP KERJA}

Solar based automatic breaking sistem yang menggunakan sensor ultrasonic HCSR04 ketika dinyalakan dibawah sinar matahari maka sinar tersebut akan menghasilkan listrik dengan tegangan $12 \mathrm{v}$ diolah oleh Solar Charger Controler untuk mencharger batre $4.2 \mathrm{v}$ yang disusun seri sehingga menghasilkan tegangan $8.4 \mathrm{v}$ yang dapat mensuplay sistem ini. Sensor ultrasonic yang tersuplay akan mendeteksi objek didepannya, ketika objek terdeteksi dengan jarak 30 cm lebih kecepatan motor tidak akan berubah atau masih tetap, ketika objek terdeteksi dengan jarak kurang dari $30 \mathrm{~cm}$ maka kecepatan motor akan menurun, semakin dekat objek terdeteksi maka kecepatan motor akan semakin menurun dan ketika jarak mencapai $5 \mathrm{~cm}$ ke bawah akan terjadilah breaking sistem.

Penurunan kecepatan pada motor akan menggunakan teknik PWM, yaitu teknik pengaturan kecepatan motor dengan mengubah nilai duty cycle. Dengan metode PWM ini motor DC diberikan sumber tegangan yang stabil dengan frekuensi kerja yang sama tetapi duty cycle pulsa kontrol kecepatan motor DC yang bervariasi. Mekanisme pengaturan ini ditangani oleh modul driver motor L298N. Modul driver L298N digunakan sebagai pengaturarah dan kecepatan motor dc, selain itu modul driver motor L298N juga dapat mengontrol 2 buah motor dc dengan arus masing-masing 4A. 
Jurnal PRAXIS | Vol. 2 | No. 2 | Maret 2020

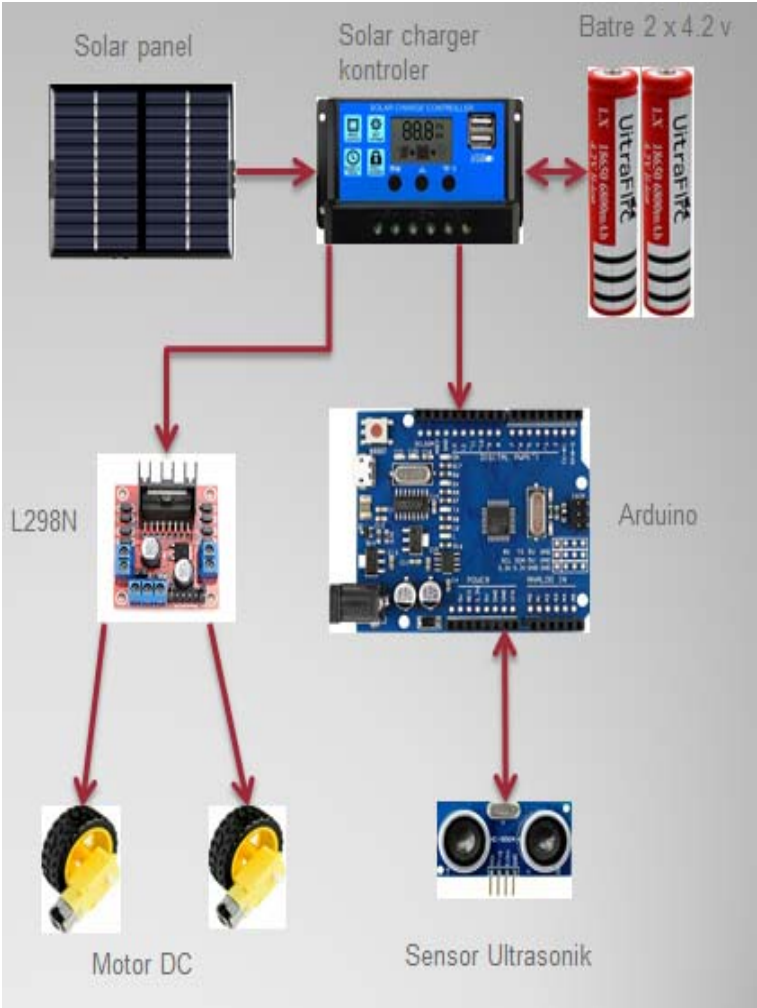

Gambar 7. Desain rangkaian

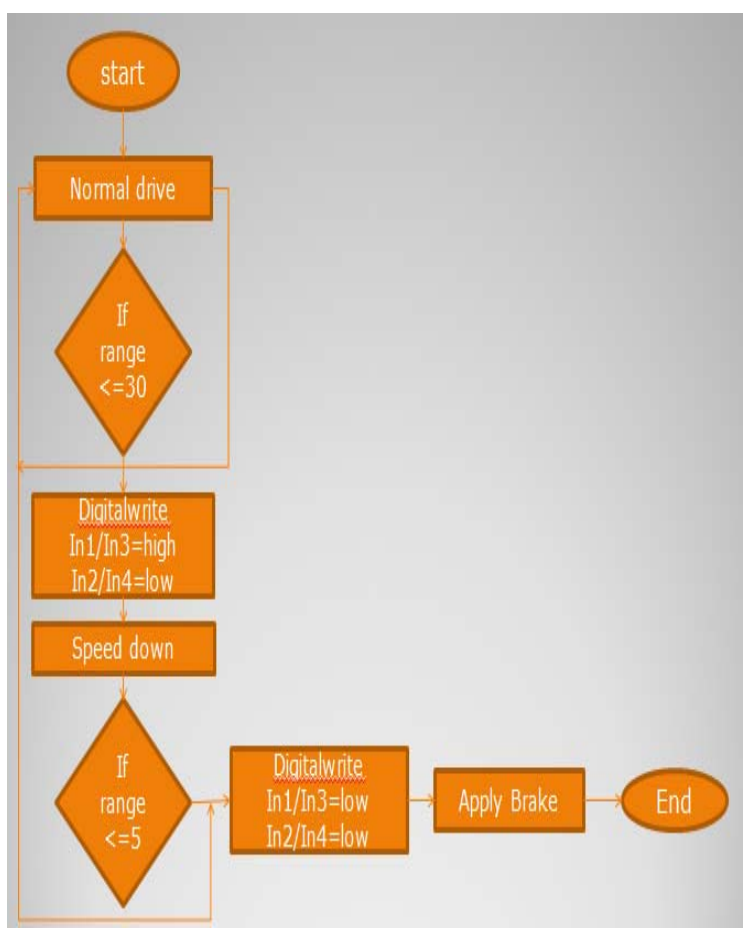

Gambar 8. Flowchart

\section{PENGUKURAN DAN PENGUJIAN}

Pada sistem ini pengujian dan pengukurannya dilakukan dengan membandingkan kecepatan PWM dengan jarak objek yang diukur menggunakan penggaris. Berikut adalah tabel hasil perbandingan antara kecepatan PWM dengan jarak objek.

Table 1. hasil pengukuran dan pengujian

\begin{tabular}{|l|l|}
\hline Range(cm) & Motor speed (\%) \\
\hline$>=30$ & $\begin{array}{l}100 \% \\
(\mathrm{max} / \text { normal) }\end{array}$ \\
\hline$>=25$ & $62,7 \%$ \\
\hline$>=15$ & $29,4 \%$ \\
\hline$>5$ & $9,8 \%$ \\
\hline$<=5$ & 00 (stop) \\
\hline
\end{tabular}

Selisih ketepatan sensor dalam mengukur jarak dengan jarak sesungguhnya yaitu sekitar 1-2 mm, dengan kondisi batre full,, ketika batre mulai lemah,, ketepatan sensor mulai tidak akurat dengan selisih hingga lebih dari $2-3 \mathrm{~cm}$ 


\section{SIMPULAN}

Berdasar pada proses perancangan, prinsip kerja, dan hasil pengujian dan pengukuran, dapat diambil kesimpulan

- Sistem bekerja dengan baik, arduino yang menerima inputan dari sensor ultrasonic dan mengolahnya untuk mengatur kecepatan motor dc dengan metode PWM

- Kecepatan mulai menurun pada jarak $<=30 \mathrm{~cm}$ dan terjadi break pada jarak $5 \mathrm{~cm}$

- Batre dapat terisi oleh solar cell dengan bantuan SCC untuk mengontrol keluaran dan masukan tegangannya

\section{DAFTAR PUSTAKA}

Fikri Musthofa, Heru Winarno. 2015. Sisrem Deselerasi Kecepatan Otomatis Pada Mobil Berdasarkan Jarak Menggunakan Sensor Ultrasonik HCSR04 Berbasis Arduino Mega 2560. Semarang : Universitas Diponegoro.
Hemalatha. 2016. Automatic Braking System for Automobiles Using IR Sensor.

Prayogo, Rudito. 2012. Pengaturan PWM dengan PLC. Tugas Mata Kuliah Teknik Otomasi (Tidak diterbitkan). Malang: Universitas Brawijaya.

Anonimus. 2013. Rangkaian Skematik Driver Motor L298N. Diunduh dari http://www.yujum.com/rangkaian-danskematik-driver-motor-1298n/ diakses pada 17 November 2019 pukul 19.45.

T. Bala Sai Goud. 2017. Automatic Braking System. Kurnool : Brindavan Institute of Technology \& Science

Gajanan Koli, Akshay Patil. 2017. Intelligent Braking System using the IR Sensor. India : Sanjeevan Engineering and Technology Institute

Anonimus. 2018. Sensor Ultrasonic HCSR04. Diakses dari http://arduinolearning.com/code/hc-sr04-ultrasonicsensor-example.php diakses pada 29 November 2019 pukul 14.30 WIB. 